УДК 94 (477.8) «1914-1917»

DOI: https://doi.org/10.33782/eminak2021.2(34).519

\title{
ОСОБЛИВОСТІ СОЦІАЛЬНО-ЕКОНОМІЧНОГО СТАНОВИЩА ВОЛИНСЬКОЇ ГУБЕРНІЇ ПІД ЧАС ПЕРШОЇ СВІТОВОЇ ВІЙНИ
}

\author{
Наталія Ковшун ${ }^{1}$, Наталія Мазур ${ }^{2}$, Ярослав Цецик ${ }^{3}$ \\ Національний університет водного господарства та природокористування (Рівне, Україна) \\ 1 e-mail: n.e.kovshun@nuwm.edu.ua; ORCID: https://orcid.org/0000-0003-0573-2932 \\ 2 e-mail: n.o.mazur@nuwm.edu.ua; ORCID: https://orcid.org/0000-0001-8673-5873 \\ 3 e-mail: slavatsetsik@gmail.com; ORCID: https://orcid.org/0000-0002-2527-2155
}

У розвідці досліджено особливості соціально-економічного становища Волинської губернії під час Першої світової війни. Проаналізовано ключові фактори, які вплинули на погіршення рівня життя населення регіону, насамперед незаможних верств. Встановлено, що в результаті відступу російських військ у 1915 р. на Волині було проведено не лише евакуацію державних установ, підприємств, середніх навчальних закладів, а й примусово виселялося місцеве населення з прифронтових повітів. Така діяльність імперської влади призвела до зубожіння величезної кількості жителів регіону. Окрема увага приділена ролі органів міського самоуправління та земств у регулюванні цін на товари першої необхідності та наданні допомоги біженцям.

Ключові слова: Волинська губернія, Перша світова війна, біженці, ціни, соціальноекономічне становище, воєнні дії, евакуація

Особливості соціально-економічного становища окремих регіонів України під час Першої світової війни досліджені недостатньо. 3’ясування ролі органів міського самоуправління та земств у вирішенні питань, пов'язаних з наданням допомоги примусово виселеним та евакуйованим жителям прифронтових повітів Волині у досліджуваний період розглянуті частково. Водночас, органи влади та місцевого самоуправління докладали значних зусиль, щоб не допустити ще більшого ускладнення ситуації у регіоні. Враховуючи загальноімперські тенденції, змінити ситуацію на краще було вкрай складно, особливо це стосувалося окупованих австроугорськими та німецькими військами західноволинських повітів.

Особливості розвитку економіки регіону на початку ХХ ст. розглянуто у праці С. Мартинчук ${ }^{1}$, зокрема, на основі фактологічного матеріалу доведено, що домінуючу роль відігравала переробка сільськогосподарської продукції. Окремі питання досліджуваної проблеми проаналізував А. Рацілевич2 . Ситуацію у західноволинських повітах на початковому етапі Першої світової війни та наслідки від ведення бойових дій детально дослідив О. Дем'янюк. Ним також розглянуто особливості суспільно-політичного розвитку регіону на початку 1917 р. й охарактеризовано причини занепаду сільського господарства у Волинській губернії4. Становище бі-

\footnotetext{
${ }^{1}$ Мартинчук С. Основні промислові заклади Волинської губернії на початку XX ст. // Актуальні проблеми вітчизняної та всесвітньої історії. Наукові записки РДГУ. 2015. Вип. 26. С. 20-22.

2 Рацілевич А. Соціально-економічні та суспільно-політичні передумови формування національного руху на Волині на початку XX ст. // Волинські історичні записки. 2008. Т. 1. С. 157-165.

3 Дем'янюк О. Західноволинські повіти на початковому етапі Першої світової війни // Краєзнавство. 2018. Вип. 4. С. 25-33.

4 Дем'янюк О. Особливості суспільно-політичного розвитку Волинської губернії навесні-влітку 1917 р. // Літопис Волині. Всеукраїнський науковий часопис. 2013. Число 13. С. 49-54.
} 
женців на українських землях, зокрема і на Волині, та причини й наслідки їхнього примусового виселення органами адміністративної влади та військовими російської армії дослідила Т.І. Лазанська5 ${ }^{5}$ Однак, питання, що стосуються ролі органів влади у регулюванні цінової політики та надання допомоги біженцям на Волині під час Першої світової війни, у наукових працях висвітлені недостатньо.

Стаття присвячена дослідженню соціально-економічного становища Волині під час Першої світової війни й аналізу факторів, які відіграли визначальну роль у зростанні цін і в погіршенні рівня життя населення.

Наприкінці XIX - на початку XX ст. Волинь була аграрним регіоном. Водночас почали простежуватися тенденції до зростання кількості великих підприємств. Напередодні Першої світової війни дві третини підприємств губернії, які створювали майже 90\% продукції за ії валовою вартістю та забезпечували зайнятість 70\% заводських робітників краю, були зосереджені на переробці рослинної сировини. Серед галузей промисловості ключову роль відігравало цукроваріння6. У 19141915 рр. на цукрових заводах було перероблено цукрових буряків на 21,8\% більше ніж у попередньому сезоні. Загальна кількість працівників підприємств галузі становила 10948 осіб, а сумарна вартість виготовленої продукції - 22,7 млн. руб. Площі посівів цукрового буряка зросли на 14\%, а врожайність - на 7\%7.

Розвитку аграрного виробництва сприяла реформа Столипіна, яка мала найбільшій успіх на території України. Число селян, які станом на 1 січня 1916 р. закріпили землю в індивідуальну власність, було найбільшим на Правобережній Україні - майже 58\%. У цей час у 40 губерніях європейської частини Російської імперії 3 «общини» вийшло лише 24\% господарів. Слід зазначити, що перешкодою реформи були високі ціни, встановлені Селянським Банком, для придбання поміщицьких земель селянами ${ }^{8}$.

На початок Першої світової війни Волинська губернія в економічному плані залишилася однією з найбільш відсталих в імперії. У 1913 р. наглядові фабричної інспекції підлягали 7,8\% від загальної кількості робітників промислових підприємств. Важким тягарем для сільського населення була наявність військових частин. До 1914 р. тут дислокувалося 45 тис. вояків російської армії, найбільша частка яких припадала на Житомир і Новоград-Волинський 9.

На початку Першої світової війни регіон став прифронтовим, а навесні-влітку 1915 р. західноволинські повіти були окуповані австро-угорською та німецькою арміями. Ще одним фактором, який погіршив соціально-економічне становище, було припинення експорту сільськогосподарської продукції. Ціни на товари першої необхідності та продукти поступово зростали, незважаючи на комплекс превентивних заходів органів імперської влади та військового командування, спрямованих на стримування зростання цін.

Отже, попри позитивну динаміку розвитку переробної промисловості, з початком ведення воєнних дій соціально-економічна ситуація почала погіршуватись. У

\footnotetext{
5 Лазанська T.І. Становище біженців України в роки Першої світової війни // Проблеми історії України XIX - початку XX ст. 2009. Вип. 16. С. 196-240.

${ }^{6}$ Мартинчук С. Вказ. пр. С. 21.

7 Обзор Волынской губернии за 1914 год. Житомир: Волынская губернская типография, 1915. C. 34-35.

8 Полонська-Василенко Н.Д. Історія України. Київ: Либідь, 1995. С. 427.

9 Рацілевич А. Вказ. пр. С. 161.
} 
результаті евакуаційних заходів значна частина промислових підприємств регіону припинила свою роботу. Частина з них були евакуйовані у віддалені від театру воєнних дій губернії.

23 липня 1914 р. у Волинській губернії, як і в усій прифронтовій зоні, ввели військовий стан. Маніфест про мобілізацію у повітові центри регіону надійшов 1819 липня 1914 p. 10

3 початку Першої світової війни соціально-економічна ситуація на Волині почала різко погіршуватися. Органи міського самоуправління, до компетенції яких належало регулювання цінової політики у містах, намагалися стримувати зростання цін. Однак значна кількість факторів, насамперед ускладнення доставки приватних вантажів залізницею, вивезення у першій половині 1915 р. значної кількості збіжжя в Галичину, діяльність військових інтендантів із закупівлі продуктів для військових частин на тлі зменшення валового їх виробництва, ускладнювало становище регіону.

Так, Житомирська міська управа доводила до відома жителів міста та торговців м'ясом, що з 27 січня 1915 р. змінюється такса на телятину. Зокрема, волинський губернатор затвердив такі, встановлені Житомирською міською управою, ціни: задня частина - 12 коп. за фунт, на котлети - 11 коп., все інше - 8 коп. за фунт. Винні у порушенні цін мали бути покарані згідно з розпорядженням військового командування 11.

Паралельно зростали ціни й на інші продукти, змінюючись практично щомісяця. У додатковій відомості до максимальних цін, опублікованих 20 лютого 1915 р. у зв'язку з їх змінами з 17 березня 1915 р., було введено нові ціни на цукор, крупи (табл. 1) та на низку інших продуктів першої необхідності.

Таблиця 1

Максимальні ціни на деякі продукти харчування у Житомирі навесні 1915 p. ${ }^{12}$

\begin{tabular}{|l|c|c|}
\hline \multirow{2}{*}{ Найменування продуктів харчування } & \multicolumn{2}{c|}{ Ціна } \\
\cline { 2 - 3 } & руб. за пуд & коп. за фунт \\
\hline Цукор-пісок на оптових складах & 4,7 & $\mathrm{X}$ \\
\hline Цукор-пісок у магазинах & 4,75 & 12 \\
\hline Крупа гречана піджарена & 3,2 & 8,5 \\
\hline Крупа гречана кращого сорту & 2,8 & 7,5 \\
\hline Крупа гречана звичайна & 2,6 & 7 \\
\hline Крупа ячна кращого сорту & 2,8 & 8 \\
\hline Крупа ячна звичайна & 1,8 & 5 \\
\hline
\end{tabular}

Навесні ситуація на фронті змінилася на користь Австро-Угорщини та Німеччини. Російська армія виявилася непідготовленою до прориву ії оборони ворожими військами у травні-червні 1915 р. У результаті російські війська були змушені відступити та зайняти оборону по лінії Холм - Володимир-Волинський - Броди - Бу-

\footnotetext{
10 Дем'янюк О. Західноволинські повіти... С. 26.

11 Державний архів Житомирської області (ДАЖО). Ф. 62. Оп. 1. Спр. 1239. Арк. 17.

12 Ibid. Арк. 22.
} 
чач. Під час відступу російська армія не лише примусово забирала з собою цивільне населення, а й руйнувала поміщицькі маєтки, спалювала села ${ }^{13}$. Щоб не допустити оточення своїх військ, яке б неминуче відбулося після відходу з Перемишля та Львова, у серпні-вересні 1915 р. російське командування, прийняло рішення про загальний відступ по всьому фронту 14 .

Воєнні дії негативно вплинули на соціально-економічне становище Волині також внаслідок проведення мобілізації працездатних чоловіків з сіл губернії, що призвело до спаду сільськогосподарського виробництва внаслідок суттєвого скорочення чисельності найбільш продуктивної робочої сили. Іншим соціальнодемографічним фактором, який негативно вплинув на економічну ситуацію в регіоні та великою мірою спричинив зростання цін на товари першої необхідності, стало збільшення кількості біженців з Галичини, потік яких у травні 1915 р. зріс у зв’язку з наступом австро-угорської та німецької армії15.

До середини осені 1915 р. було евакуйовано шість повітів Волині: ВолодимирВолинський, Ковельський, Острозький, Дубенський, Луцький і Рівненський. Проводилася підготовка до евакуації: Новоград-Волинського, Житомирського, Кременецького повітів і Житомира. У звіті евакуаційної комісії відзначалося, що з евакуйованих повітів було вивезено всі підприємства, а також з Ізяславського, Старокостянтинівського та Новоград-Волинського повітів. У Новоград-Волинському повіті у зв'язку з евакуацією не працювало 12 фабрик і заводів 16.

Під час наступу австро-угорської армії влітку 1915 р., окрім евакуації промислових підприємств, державних установ і навчальних закладів, з прифронтових повітів примусово виселяли і селян. Ставка, керуючись «воєнною доцільністю», у липні 1915 р. «вдалася до дій по очищенню деяких ділянок фронту». У середині серпня було оголошено про евакуацію з 150-200-верстової прикордонної смуги Волинської, Подільської та Бессарабської губерній. На цей раз примусовому виселенню підлягало працездатне населення віком від 12 до 50 років з одночасним знищенням запасів продовольства, реквізицією та вивезенням худоби і коней. Це призвело до повного розорення місцевого населення 17.

У західних повітах Волинської губернії негативні явища на продовольчому ринку спостерігалися ще напередодні евакуації. Для їх врегулювання органами влади було створено Продовольчі комітети. У журналі Особливої наради з питання організації у м. Кременець Продовольчого комітету під головуванням повітового предводителя дворянства Д.Е. Журавського відмічалося, що волинський губернатор циркулярним розпорядженням губернському в міських і земських справах присутствію надіслав копію результатів наради, яка відбулася 1-2 квітня 1915 р., де розглядалися питання про забезпечення міст, які «особливо потребували», та населення повітів продуктами ${ }^{18}$.

12 травня 1915 р. голова Кременецької повітової земської управи звернувся до волинського губернатора з клопотанням, в якому увага акцентувалася на тому, що

\footnotetext{
13 Дем'янюк О. Західноволинські повіти... С. 28.

14 Ibid. C. 30.

15 Цецик Я. Соціально-економічна ситуація у Волинській губернії напередодні та під час Першої світової війни // Наукові записки Вінницького державного педагогічного університету імені Михайла Коцюбинського. Серія: Історія. 2020. Вип. 31. С. 39.

16 Дем'янюк О. Західноволинські повіти... С. 30-31.

17 Лазанська Т.І. Вказ. пр. С. 200.

18 ДАЖО. Ф. 70. Оп. 2. Спр. 10. Арк. 46.
} 
«з кожним днем створювалося безвихідно-важке становище для прикордонного Кременецького повіту внаслідок непомірно швидкого підвищення цін на життєві продукти». Це призвело до різкого зростання оплати праці робітників і «найняття підвід»19.

Підвищення цін та оплати праці доходило до такої «висоти, коли правильний перебіг сільськогосподарського життя, рівно й існування найбідніших верств як сільського, так і міського населення ставали вкрай важкими». У повіті весняні польові роботи проходили у надзвичайно складних умовах. Для найбідніших верств населення та для родин запасних чинів, призваних на військову службу в діючу армію, у селах, де місцеві громади відмовлялися допомогти засіяти їхні поля, плата за користування плугом становила 6 руб. на день, що поставило їх у «вкрай важке становище». Селяни засівали поля, зменшивши частку витрат на харчування власних родин. Багато людей «жили впроголодь», однак не всі змогли провести весняні польові роботи через брак коштів. Незаможні верстви міського населення також переживали важкі часи. Вони були не в змозі платити за продукти, які подорожчали вдвічі 20.

Аналогічні тенденції спостерігалися і в інших повітах Волинської губернії. Так, на початку Першої світової війни, 14 серпня 1914 р. у м. Дубно було встановлено максимальні ціни на такі продукти харчування, як м'ясо, хлібобулочні вироби, картоплю, цукор і сіль. Зокрема, яловичина I сорту мала коштувати 12 коп. за фунт, II сорту - 10 коп., свинина окіст - 16 коп. за фунт, філе - 18 коп., лопатки, ребра та м'ясо - 13 коп., голова, хребет - 8 коп., печінка, селезінка та легені - 5 коп. за фунт. Ціна на хлібобулочні вироби становила від 8 коп. за фунт - 3 муки сорту екстра до 3 коп. за фунт - з разової житньої муки. Картопля коштувала 20 коп. за пуд, а в січні 1915 р. подорожчала до 22 коп. Тоді ж подорожчав і на 2 коп. цукор до 16 коп. за фунт. Сіль кам'яна не мелена коштувала 50-70 коп. за пуд, мелена - 60-90 коп. ${ }^{21}$

20 січня 1915 р. Дубенські міські уповноважені розглядали заяву власників млинів, які звернулися до міського самоуправління, щоб міська Управа звернула увагу на складну ситуацію у борошномельній промисловості повіту, адже за своїм «географічним розташуванням він повинен відігравати важливу роль у постачанні борошном нашого регіону й значної частини Галичини». Варто зауважити, що напередодні війни борошномельна промисловість у Дубенському повіті розвивалася швидкими темпами, чому сприяла наявність родючих чорноземів. Власники борошномельних підприємств використовували зерно й з інших губерній імперії. У зв'язку зі зростанням закупівель військового інтендантства та зростанням попиту на зернові у Галичині та «близьких районах» їхні запаси вичерпалися. У результаті заборони відвантажувати зерно з тих районів, де його було вдосталь, і воно «гниє без користі, ми не маємо можливості його придбати й перевезти»22. Така ситуація пояснювалася неможливістю залізниці доставляти всі необхідні вантажі. Насамперед вона намагалася забезпечити потреби діючої армії.

Міська Управа м. Дубно пішла назустріч власникам млинів і порушила клопотання перед губернатором про надання дозволів на позачергове відвантаження та перевезення зерна. На заваді їх безперебійному функціонуванню став Порайонний

\footnotetext{
19 Ibid. Арк. 56.

20 Ibid. Арк. 56.

21 Державний архів Рівненської області (ДАРО). Ф. 359. Оп. 1. Спр. 13. Арк. 37.

22 Ibid. Арк. 19.
} 
комітет, який задовольняв цю умову лише частково, скорочуючи необхідну кількість вагонів для перевезення, і зерно часто прибувало із запізненням. 3 деяких віддалених регіонів Сибіру та Центральної Росії його взагалі забороняли перевозити. Внаслідок створених Порайонним комітетом перешкод у регіоні «розпочався майже голод на зерно», що спричинило штучне зростання ціни на борошно. Від цього страждало не лише населення Волинської губернії. Зникли також можливості поставляти муку в Галичину, внаслідок чого ціни на нього зросли і там 23.

Отже, неможливість залізниці впоратися з усім обсягом перевезень, який значно зріс в умовах воєнного часу, призвела до неможливості поставляти сировину для борошномельних підприємств. Така позиція органів влади диктувалася, насамперед, необхідністю забезпечити потреби діючої армії.

Тогочасна ситуація не лише не сприяла економічній стабільності, а навпаки спричинила зростання цін на продукти. Так, 20 січня 1915 р. на засіданні Дубенських зборів міських уповноважених з 29 січня у місті було встановлено наступні ціни на яловичину I сорту - 13 коп., II сорту - 11 коп. за фунт ${ }^{24}$. Суттєво зросли ціни і на такий продукт першої необхідності, як хліб (табл. 2).

Таблиця 2

Тенденції зростання цін на хлібобулочні вироби у м. Дубно протягом серпня 1914 - січня 1915 рр. 25

\begin{tabular}{|l|c|c|c|}
\hline \multirow{2}{*}{$\begin{array}{c}\text { Найменування хлібобулочних } \\
\text { виробів }\end{array}$} & \multicolumn{2}{|c|}{ Ціна, коп.фунт } & Темп зрос- \\
\cline { 2 - 3 } & $\begin{array}{c}\text { встановлені з } \\
14.08 .1914 \text { р. }\end{array}$ & $\begin{array}{c}\text { встановлені 3 } \\
29.01 .1915 \text { р. }\end{array}$ & $\begin{array}{c}\text { тання цін, } \\
\%\end{array}$ \\
\hline $\begin{array}{l}\text { 3 муки сорту екстра (прикраше- } \\
\text { ні) }\end{array}$ & 8 & 10 & 125,0 \\
\hline з муки вищого сорту & 6 & 8 & 133,3 \\
\hline з муки нижчого сорту & 4 & 6 & 150,0 \\
\hline хліб житній питльованій & 4 & 5,5 & 137,5 \\
\hline з разової та питльованої муки & 4 & 5 & 125,0 \\
\hline з разової житньої муки & 3 & 4 & 133,3 \\
\hline
\end{tabular}

Таким чином, якщо ціни на хлібобулочні вироби з дорожчих сортів муки, зорієнтовані на споживання заможними верствами населення, зросли на 25-30\%, то подорожчання хлібу з муки нижчого сорту відбулося у 1,5 рази, що суттєво ускладнило становище незаможного населення.

Як видно з вищенаведених документів, несвоєчасне підвезення зернових, що було зумовлено перебоями у роботі залізничного транспорту, не лише спричинило зростання цін, а й поставило на межу голоду окремі повітові міста регіону. Насамперед, це стосувалося населених пунктів наближених до Галичини, яка на той період була окупована російськими військами. Найбільший тягар падав на незаможне міське населення, для якого зростання цін особливо негативно позначалося на рівні життя.

\footnotetext{
23 ДАРО. Ф. 359. Оп. 1. Спр. 13. Арк. 19.

24 Ibid. Арк. 36.

25 Ibid. Арк. 36-37.
} 
В іншому документі, датованому лютим 1915 р. й адресованому міським головам і міським старостам Волинської губернії, констатувалося, що одним із головних завдань уряду й органів місцевого самоврядування у «цей важкий період» було прийняття заходів для «забезпечення населення необхідними предметами продовольства». У зв'язку з цим вони були зобов'язані вести боротьбу зі спекуляцією, яка розвивалася на тлі народних страждань, щодо торговців, які намагалися «недобросовісно збагатитися у важку хвилину». Для попередження спекуляції з боку торговців, командуючим Київським військовим округом ще на початку війни було видано обов'язкову постанову, яка забороняла штучно підвищувати ціни на всі предмети вжитку місцевим населенням. Винні в її порушенні підлягали адміністративному покаранню, ув'язненню до трьох місяців чи штрафу до 3 тис. руб. 26

Таким чином органи влади та військового командування намагалися протидіяти штучному підвищенню цін на продукти харчування та товари першої необхідності. Однак ці заходи не завжди давали потрібний ефект. Місцеві торговці змушені були звертатися до органів місцевого самоуправління з клопотанням про підвищення цін, що було продиктовано загальноімперськими тенденціями подорожчання продуктів харчування та товарів першої необхідності у Російській імперії у досліджуваний період.

Ще однією проблемою, яка негативно впливала на соціально-економічне становище регіону, стали перебої з підвезенням солі. 3 цього приводу земським управам і міським громадським управлінням Волинської губернії було надіслано циркулярне розпорядження. У ньому наголошувалося, що згідно з Постановою міністра землеробства від 22 квітня 1916 р. за № 29, розісланою циркуляром від 28 квітня 1916 р. № 1362, Соляним комітетам було поставлено завдання забезпечити можливість закупівлі солі за цінами, які не перевищували твердих, зі своєчасним її відвантаженням для низки губерній «позапланово». До цього переліку належала і Волинь. Згідно з постановою Розпорядчого комітету від 29 березня 1916 р. перевезення солі мало здійснюватися за «особливим планом, складеним управлінням справами Особливої наради з продовольчої справи», який затверджувався Розпорядчим комітетом. У губерніях, які потрапляли під дію даної постанови, уповноважені Продовольчого комітету до 1-го числа кожного місяця мали передавати у Соляні комітети відомості про необхідну кількість вагонів для перевезення солі та про залізничні станції призначення ${ }^{27}$. У результаті частина повітів Волині отримала можливість підвезення солі, що повинно було стабілізувати її вартість. На момент прийняття даного рішення це стосувалося лише неокупованих австроугорськими та німецькими військами повітів.

Досліджуючи соціально-економічні процеси у регіоні, доцільно проаналізувати особливості матеріального забезпечення різних категорій населення тогочасної Волинської губернії. Незважаючи на зростання цін, рівень заробітної плати залишався на довоєнному рівні. У відомості на виплату заробітної плати за липень 1916 р. зазначено, що директор Коростишівської учительської семінарії отримував на місяць 96 руб. заробітної плати і 64 руб. столових, з яких загалом вираховували 3,2 руб, на рік - відповідно 1152 та 768 руб. Вчитель закону Божого - відповідно 54,17 руб. зарплатні та 45,83 руб. столових, тобто загалом 100 руб на місяць, і з цієї

\footnotetext{
26 Державний архів Волинської області (ДАВО). Ф. 3. Оп. 1. Спр. 1458. Арк. 1.

27 ДАВО. Ф. З. Оп. 1. Спр. 1576а. Арк. 7.
} 
суми вираховували 2 руб. Вчитель російської мови - 52 і 44 руб., вчитель природознавства й сільського господарства - відповідно 54 і 42 руб. та 20 руб. квартирних, разом - 116 руб., вчитель графічного мистецтва - 24,5 і 16,33 руб., тобто в сумі 40,83 руб., вчитель ручної праці - 49 руб. заробітної плати, 16,33 руб. столових і 12 руб. квартирних, із загальних виплат кожного з них також вираховували 2 руб.28 Значно нижчою була заробітна плата вчителів початкових училищ. Завідувач Луцького міського приходського училища в 1914 р. отримував 360 руб. з казни та 180 руб. з міського бюджету, що становило 540 руб. на рік, вчитель - відповідно 360 руб. і 40 руб., вчитель закону Божого - 180 руб. від казни, вчителька - 360 руб. від казни, а за навчання співам виплачували 100 руб. з коштів, які виділялися органом міського самоуправління ${ }^{29}$. Для порівняння, згідно з відомістю про отримання заробітної плати городовими 2-ї поліцейської частини Житомиру за лютий 1915 р., вони у середньому отримували 20-25 руб. Частина з них отримували надбавку за «вислугу», яка складала від 4,16 до 8,33 руб. ${ }^{30}$

Таким чином, заробітна плата різних категорій службовців була неоднаковою. При цьому варто зазначити, що частина з них отримувала квартирні та столові кошти. Певні додаткові виплати мали і поліцейські.

Ситуація із зростанням цін спостерігалася у багатьох населених пунктах. Органами міського самоуправління вводилися посади уповноважених, які повинні були контролювати наявні запаси продовольства згідно з розпорядженням волинського губернатора. Житомирська міська дума для виконання цих функцій призначила гласного Ксенджепольського та виділила йому 50 руб. для поїздок. Він повинен був 2-3 рази на місяць проводити перевірки торговельно-промислових підприємств, які «займали досить багато часу». У той же день гласні міської Думи прийняли рішення збільшити ціну на свинину: філе - 28 коп. за фунт, окіст - 25 коп., сало I сорту - 38 коп., II - 35 коп., інше - 22 коп. за фунт 31 .

Одним з ключових факторів, що вплинув на погіршення соціально-економічної ситуації та зростання дефіциту продуктів, відіграло примусове виселення населення з прифронтових повітів. Кількість біженців підрахувати надзвичайно складно, адже часто їх облік не здійснювався. 3 цього приводу у газеті «Жизнь Волыни» констатувалося, що хвиля біженців, як потік, наповнила Східну Волинь і сусідні губернії. Чи було можливо представити картину страждань людей ХХ ст., які «подібно до дикунів потрапили у ліси та болота під відкрите небо й не визнають ніяких зручностей цивілізації». I далі «йшов цей бездомний відірваний від землі, вогнища іноді й сім'ї, нервовий, напівголодний переселенський натовп», без мети та надії на майбутнє $\epsilon^{32}$.

Для надання допомоги біженцям на всій території країни «енергійно працювали комітети допомоги». Волинським губернським земством було відкрито 105 пунктів харчування та 30 медичних. На залізничних станціях функціонувало 20 пунктів, з яких біженців відправляли у Катеринославську та Курську губернії. На пунктах щоденно харчувалося близько 300 тис. біженців. Розпочали роботу майстерні, в яких вони мали змогу безкоштовно підкувати коней і відремонтувати во-

\footnotetext{
28 ДАЖО. Ф. 75. Оп. 1. Спр.644. Арк. 5-6.

29 ДАВО. Ф. 3. Оп. 1. Спр. 1130. Арк.8зв.-9.

30 ДАЖО. Ф. 62. Оп. 3. Спр. 8. Арк. 95-97.

31 Заседание городской думы // Жизнь Волыни. 1916. 25 марта. С. 1-2.

32 Беженцы // Жизнь Волыни. 1915. 24 сентября. С. 1-2.
} 
зи. Витрати на біженців передбачалися значні. У майбутньому держава планувала взяти їх «під свій патронат». Однак на той момент пріоритетом була армія, яка «рятувала честь і гідність держави та родини біженців - ось наша майбутня турбота і піклування»33.

Величезна кількість біженців, які заполонили Волинь після відступу російської армії влітку 1915 р., ще більше загострила соціально-економічну ситуацію у губернії. Органи адміністративної влади виявилися не готовими до комплексного вирішення питань, пов'язаних із наданням належної допомоги примусово виселеним і біженцям. Губернське та повітові земства, органи міського самоуправління не мали відповідних фінансових ресурсів для цього. Але саме вони робили усе залежне від них, щоб надати допомогу продуктами, одягом, і відправити людей у східні губернії.

Упродовж 1915-1916 рр. регіон зіштовхнувся ще з однією складною проблемою - інфекційними захворюваннями.

Після літнього наступу російських військ 1916 р. частина повітів Волині була звільнена. Однак, соціально-економічне становище населення у них було надзвичайно складним. На засіданні уповноважених у м. Дубно 31 серпня 1916 р. було розглянуто питання подорожчання палива та запровадження заходів для протидії зростанню цін на товари першої необхідності. Враховуючи складнощі, які виникали з перевезенням палива, було прийнято рішення розпочати його заготівлю з метою «відпуску населенню дров» за заготівельними цінами. Також було розпочато підготовку клопотання до Особливої наради про можливість об’єднання заходів та отримання від державної скарбниці позики для придбання палива за «дешевшими цінами» 34 .

Волинський губернатор П. Скаржинський звернувся до губернського земства 3 телеграмою, в якій зазначалося про можливість отримання кредитів з метою «задоволення продовольчих потреб» звільнених повітів. Потрібно було визначити потребу в зерні та борошні у Дубенському та Луцькому повітах, направити для населення крупи тощо. Губернатор краю пропонував попросити у генерала Ердмана дозволу на тимчасове отримання продовольства у військових. 3 дозволу генерала Ердмана щоденно відпускали 15 голів великої рогатої худоби: 10 для м. Луцьк і 5 для м. Дубно 35 .

3 метою відновлення зруйнованого тваринництва було заплановано відкрити розплідник для 2 тис. телят, закупити 2 тис. свиноматок тощо. Цим питанням мав опікуватися агрономічний відділ губернського земства. Клопотали надати безвідсоткові позики терміном на рік для закупівлі 10 тис. коней по 100 руб. за голову, 5 тис. возів по 120 руб., і на придбання упряжі й сільськогосподарського реманенту. Було також наголошено на потребі першочергового відвантаження вантажів звільнених повітів. На все це губернське земство мало отримати безвідсоткові позики терміном на один рік ${ }^{36}$.

Отже, ключову роль у відновленні зруйнованого війною господарства органи влади покладали на земства. Єдина підтримка, на яку вони могли розраховувати

\footnotetext{
33 Ibid. C. 1-2.

34 ДАРО. Ф. 359. Оп. 1 Спр. 14. Арк. 87.

35 Обеспечение населения освобождённых уездов Волыни продовольствием // Жизнь Волыни. 1916. 4 июня. С. 3.

36 Ibid. C. 3.
} 
від органів імперської влади, - це отримання безвідсоткових кредитів від державної скарбниці на незначні терміни.

У селах звільнених повітів становище населення було надзвичайно складним. Навіть у тих, які не були зруйновані війною, у селян зерна вистачило лише до грудня-січня 1916 р. Крупи та борошно часто взагалі були відсутніми. Багато селян не мали можливості перемолоти власне зерно. Млини, які були недалеко від лінії фронту, часто потрапляли під ворожі обстріли. Більш віддалені були завантажені і доставити туди зерно за 25-30 верст було надзвичайно складно 37.

3 посівів 1915-1916 рр. селяни зібрали лише озимі, а ярові культури були знищені військами. У багатьох населених пунктах, зважаючи на ведення боїв, його взагалі не зібрали. Не всюди вдалося зібрати також врожай картоплі. Селяни боялися, що у них вкрадуть залишки врожаю, тому не залишали рідних місць ${ }^{38}$.

Лише в окремих населених пунктах, де вдалося зібрати $1 / 5$ врожаю ярих культур, селяни були більш-менш забезпечені продовольством. У частині з них зібраний врожай залишався на полі у скиртах, його не могли вивезти через обстріли, в інших - на селянських подвір'ях. У порівнянні з довоєнним часом ціни на продукти суттєво зросли. Булка, яка раніше коштувала 1-2 коп., подорожчала до 17,5 коп., тобто у 9-17 разів; пуд картоплі став коштувати 1,5 руб.; яйця - 15-20 коп. за шт., цукор - 80 коп. за фунт тощо. Якщо й довозили зерно до млина, то перемел коштував 25 коп. за пуд. Населення скаржилося на неможливість придбати товари першої необхідності. Магазин, який знаходився у Торчині й перебував у віданні комітету Південно-Західного фронту, часто взагалі був без продовольства 39.

Зростання цін на продукти харчування негативно позначилося, насамперед, на рівні життя незаможних верств населення. Значна частка населення потребувала продовольчої допомоги. Багато родин харчувалися тим, що купували, або хлібом, який «вдавалося випросити у солдатів». Жінки заробляли пранням білизни для солдатів. Велика рогата худоба та коні були захоплені австрійськими військами під час відступу, або знищені. Це саме стосувалося птиці, свиней і кіз. У багатьох населених пунктах не було посіяно озимих, або вдалося засіяти незначні площі у зв’язку з відсутністю насіння 40.

Справдилися також прогнози щодо невдалої цукрової кампанії на Волині у 1916 р. 317 цукрових заводів у краї працювало 13, чотири були евакуйовані. 3 них лише 8, і то із запізненням майже на місяць, приступили до роботи. Робота на заводах заледве налагоджувалася, а деякі з них взагалі призупиняли виробництво через відсутність сировини. Однак, незважаючи на складну ситуацію, власники цукрових заводів отримували значні прибутки завдяки зростанню ціни на оптовий продаж цукру ${ }^{41}$.

Найвідчутніше війна вдарила по малозабезпечених верствах сільського населення. Станом на початок березня 1917 р. близько 20\% селянських господарств не мали посівів, у понад 60\% реквізували коней для потреб армії. В окремих селах не залишилося жодного коня. Навесні 1917 р. частина селян обробляли поля лопатами, мотиками, іноді самі впрягалися у плуг і по черзі орали ${ }^{42}$. Станом на березень

\footnotetext{
37 В освобождённых местах Владимир-волынскаго уезда // Жизнь Волыни. 1916. 10 ноября. С. 5. 38 Ibid. C. 5.

39 Ibid. C. 5.

40 Ibidem.

${ }^{41}$ Сахарная кампания на Волыни // Жизнь Волыни. 1916. 17 октября. С. 4.

42 Дем'янюк О. Особливості суспільно-політичного... С. 52.
} 
1917 р. регіон перебував у занедбаному стані. Майже 70\% працездатних чоловіків було мобілізовано до російської армії чи переселено вглиб імперії. Площі посівних, у порівнянні з 1913 р., зменшилися на понад 2 млн. десятин. Прифронтові повіти Волинської губернії вражали зруйнованими чи напівзруйнованими селами та хуторами, спустошеними та занедбаними землями ${ }^{43}$.

Отже, наприкінці 1916 - на початку 1917 рр. у сільському господарстві Волині склалася критична, у порівнянні з довоєнним періодом, ситуація. Величезні площі навіть не були оброблені, що було зумовлено кількома факторами. Насамперед, мобілізацією чоловіків у діючу армію, проведенням реквізицій худоби військовими як російської, так і австро-угорської армій, недостатньою кількістю насіння, відсутністю допомоги сільському населенню з боку органів влади. У найгіршій ситуації опинилися західні повіти Волині, що були звільнені внаслідок Брусиловського прориву 1916 р.

Таким чином, під час Першої світової війни соціально-економічна ситуація у Волинській губернії різко погіршилася у порівнянні з довоєнним періодом. Стрімке зростання цін, у т.ч. на продукти харчування та предмети першої необхідності при незмінних заробітних платах, мобілізація до армії працездатних сільських чоловіків, розорення або знищення внаслідок військових дій сільських господарств і промислових підприємств, примусове виселення частини працездатного населення у східні губернії, призвели до значного погіршення соціально-економічного становища краю та погіршення рівня життя населення, яке залишилося на території воєнних дій, часто до стану зубожіння. На відновлення руйнувань, що їх зазнала Волинська губернія під час ведення воєнних дій, потрібен був значний період часу та величезні інвестиції у сільське господарство і промисловість, а уряд та органи влади займалися, насамперед, забезпеченням армії.

\section{REFERENCES}

Demianiuk, 0. (2018). Zakhidnovolynski povity na pochatkovomu etapi Pershoi svitovoi viiny [West Volyn counties at the initial stage of the First World War]. Kraieznavstvo, 4, 25-33 [in Ukrainian].

Demianiuk, 0. (2013). Osoblyvosti suspilno-politychnoho rozvytku Volynskoi hubernii navesni-vlitku 1917 r. [Features of socio-political development of the Volyn province in the Spring and Summer of 1917]. Litopys Volyni. Vseukrainskyi naukovyi chasopys, 13, 49-54 [in Ukrainian].

Lazanska, T.I. (2009). Stanovyshche bizhentsiv Ukrainy v roky Pershoi svitovoi viiny [The situation of refugees in Ukraine during the First World War]. Problemy istorii Ukrainy XIX - pochatku XX st., 16, 196-240 [in Ukrainian].

Martynchuk, S. (2015). Osnovni promyslovi zaklady Volynskoi hubernii na pochatku XX st. [The main industrial institutions of the Volyn province in the early XX century]. Aktualni problemy vitchyznianoi ta vsesvitnoi istorii. Naukovi zapysky RDHU, 26, 20-22 [in Ukrainian].

Polonska-Vasylenko, N.D. (1995). Istoriia Ukrainy [History of Ukraine]. Kyiv: Lybid [in Ukrainian].

Ratsilevych, A. (2008). Sotsialno-ekonomichni ta suspilno-politychni peredumovy formuvannia natsionalnoho rukhu na Volyni na pochatku XX st. [Socio-economic and socio-political prerequisites for the formation of the national movement in Volyn in the early XX century]. Volynski istorychni zapysky, 1, 157-165 [in Ukranian].

Tsetsyk, Ya. (2020). Sotsialno-ekonomichna sytuatsiia u Volynskii hubernii naperedodni ta pid chas Pershoi svitovoi viiny [Socio-economic situation in Volyn province on the eve and during the First World War]. Naukovi zapysky Vinnytskoho derzhavnoho pedahohichnoho universytetu imeni Mykhaila Kotsiubynskoho. Seriia: Istoriia, 31, 37-44 [in Ukranian]. 


\section{Nataliia Kovshun}

(National University of Water and Environmental Engineering, Rivne, Ukraine)

e-mail: n.e.kovshun@nuwm.edu.ua

ORCID: https://orcid.org/0000-0003-0573-2932

\section{Nataliia Mazur}

(National University of Water and Environmental Engineering, Rivne, Ukraine)

e-mail: n.o.mazur@nuwm.edu.ua

ORCID: https://orcid.org/0000-0001-8673-5873

\section{Jaroslav Tsetsyk}

(National University of Water and Environmental Engineering, Rivne, Ukraine) e-mail: slavatsetsik@gmail.com

ORCID: https://orcid.org/0000-0002-2527-2155

\section{Peculiarities of Social and Economic Conditions of Volyn Province During the First World War}

The peculiarities of the social and economic conditions of Volyn Province during the First World War are considered in the study. The reasons for the development of the agricultural sector of the economy and its impact on the development of industry on the eve of the war are clarified. As a result of the region's proximity to the theater of operations and the conscription of men into the active army after the start of hostilities in 1914, there was a shortage of employees in the agricultural sector. At the same time, the wages of employees increased. That caused the fact that in Western counties of Volhynia some of the agricultural lands in 1915 remained uncultivated. The key factors that influenced the deterioration of living standards of the region's population, first of all, the poor, are analyzed in the paper. It is noted that the taking out of food from the region for the needs of the active army and the population of Galicia, which was occupied by Russian troops at the initial stage of the war, led to difficulties with the supply of some towns in the region.

It is found out that as a result of the retreat of Russian troops in 1915, not only state institutions, enterprises, and secondary schools were evacuated from Volhynia, but also the local population was forcibly evicted from frontline counties. Such activities of the imperial power led to the impoverishment of a huge number of residents of the region. Particular attention is paid to the reasons for rising essential goods prices and the role of municipalities and zemstvos in their regulation and assistance to refugees. Based on an unbiased study of the documents, it is found that after the liberation of part of West Volhynia counties by the Russian troops, the social and economic situation in them was extremely tense. The vast majority of the rural population lacked not only seeds and livestock but also food. This, in turn, led to growing dissatisfaction with the actions of the imperial power, which was primarily concerned with supplying the army.

In that situation, the provincial and county zemstvos made significant efforts to revive the war-torn agricultural sector. However, those plans did not improve the situation in the wartorn counties of Volyn Province and in most cases remained projects due to lack of funding.

Keywords: Volyn Province, the First World War, refugees, prices, social and economic situation, hostilities, evacuation 